\title{
The Role of Teachers' Experiential Learning and Reflection for Enhanching their Autonomous Personal and Professional Development
}

\author{
Adi Suryani, Tri Widyastuti
}

\begin{abstract}
Today's teachers are not only teaching, but they have to fulfill various educational roles. This situation demands teachers to learn continuously. They should develop themselves to improve students' achievement. To grow continuously, teachers should not just wait for formal, instructed or top-down training or learning. They should be autonomous and self directed. They should be aware and analyze what they need and how they should obtain knowledge or skill that they need. Autonomous teachers learn by reflecting their daily teaching and learning experiences. They use their experience as opportunity to learn. There are three main sources of teachers' learning: their teaching experiences, sharing ideas in professional communities, and by researching.

Keywords: professional development, learning from experiences, professional communities, researching, reflection
\end{abstract}

\section{Introduction}

Teachers are at the heart of educational process. The greater the importance attached to education as a whole-whether for cultural transmission, for social cohesion and justice, or for human resource development so critical in modern, technology-based economies-the higher is the priority that must be accorded to the teachers responsible for that education (OECD, 1989, cited in Day, 1999, p. 1).

The above excerpt shows us that teachers' role is significant in all aspects of life. Teachers have duty to facilitate development or progress in educational sector. The progress within the educational sector lays the foundation for sustaining development in other areas.

If we talk about educational development, the first factor which we may consider is the teachers: the teachers' education, background, teachers' beliefs, attitudes, and values towards teaching and learning, teachers' learning and professional development. It is apparent that as the key figures in education, teachers have significant roles in affecting students' learning motivation and outcomes. Thus, 
when our students are failing, it is necessary to observe, examine and evaluate broader context instead of only a narrow setting. When we consider and assess the broader context, we can see that there are other factors affecting students' achievement, for instance teachers, schools, or educational system factors. If we it from the narrower perspective, we may evaluate that students' failure roots in students aspect. This narrower perspective may inhibit our explorative effort to develop education. This implies that teachers, as one of several affecting factors, should be taken into account in education.

Today's teachers are different from previous ones. Every era has its own type of teachers. Different society entails different situation and demands. Today's society needs many skillful human resources to work in nowadays more developed areas than before. This encourages teachers to work harder to improve the quality of their students. However, teachers cannot improve their students' learning without starting improving their own learning (quality). This means that they should engage in professional development activities. They should improve their knowledge, their teaching methods and their behavior. It is becoming apparent now that teachers should not only to develop their cognition, but also meta-cognition. They should only know the knowledge, but also understand the why and how to get that knowledge. This means that they understand how to learn to develop. They comprehend learning content and learning behavior.

The heart of teachers' personal and professional development is changing teachers' perspective, belief and value towards learning. It is not sufficient to only send teachers to formal training, especially when the teachers feel they do not need the training, but because their headmasters say so, then they have to attend the training. This indicates that teachers' professional development should be initiated from teachers' personal context. Teachers should feel that they need to improve their quality, develop inner/internal motivation and have self-awareness. By possessing internal passion to improve themselves, they will try to find ways to develop instead of waiting opportunity to progress. Thus, it is essential for teachers to be able to manage their own personal and professional development. It is important for teachers to move from their status quo, their comfort zone to grow. When they think 
working on students' achievement, they should start thinking working on increasing themselves.

By possessing self-regulated professional development, teachers can explore their environment as source of learning. They do not have to wait for formal training to improve themselves. They can engage in experiential through their professional activities, for instance teaching, researching, or discussing with their colleagues. Those types of learning can be effective since teachers can improve themselves contextually. They can develop based on what they need, what their students need and what their schools require/demand. This process will be meaningful if teachers perform reflection on their experience. By performing reflective experiential learning, teachers are not only learning outcome of their activities, but also the process or the how aspect. Understanding the process they can find the meaning of doing the learning and are able to repeat the process.

In the area of second language teaching, non-native second language teachers also have chalenges. They have to teach language which is not their own language. They get this language through learning. Therefore, to improve their competency, they should maintain their exposure to this language even they have to increase their mastery (competence). They have to find ways to enhance their personal and professional development.

\section{Problems of the Study}

In this study, I intend to discuss two main problems:

1. How can second language teachers perform autonomous (self-ditected) personal and professional development?

2. How can second language teachers' personal and professional development can be supported by teachers' reflection? How is the roles of teachers' reflection?

\section{The Foundation of Teachers' Development}

Today's teachers are different from previous teachers. Recently, education should adapt to the development of society and requires educational reform (Ifanti \& 
Vasiliki, 2011; Thomas, 1995). Our modern society needs more expert and skillfull human resources which are practically competent in their areas and have higher capacity in problem solving. Thus, the education should change from teachercentred learning into student-centred learning. This changing encourages teachers to serve different roles and increase their professionalism in performing their new function (Ifanti \& Vasiliki, 2011).

Teachers should change their roles from becoming the sources of information into facilitating information. As mentioned by Esteve (2000), teachers should be transformed from teaching only into facilitating, coordinating, organizing and councelling their setudents' learning. Becoming learning facilitators is not simpler than becoming source of information. This is because teachers should equip themselves with more than content knowledge, but also knowledge on managing classroom, creating materials and assessment, teaching method, managing their students' behaviour and improving themselves. They play various roles. Teachers should not be able to transfer vital information to their students and manage their classroom, but also should enable their students to know how to learn various and complex things (Darling Hammond, 2006, p. 1). Teachers should become active designer, active listener, actor/director, assigner, case designer (organizer), coach, consultant, content expert, coordinator, discussion facilitator, formative evaluator, grader, lecturer designer, materials/organizer, mini lecturer, negotiator, non-directive facilitator, prescriptive advisor, process observer, questioner, resource manager, resource person, and role model (Grasha, 2002, pp. 19-20). Furthermore (Grasha, 2002 , p. 35) classifies roles of teachers into three main functions: as knowledge container, journey guide, and master discipline. Teachers should also be “diagnosticians, knowledge organizers, and skilled coaches" (Darling-Hammond, 2006). It is expected that teachers' various roles in managing classroom and teaching can affect students' learning achievement. Thus, teachers should develop themselves for improving their own self and their students. This is as shown in the following figure. 


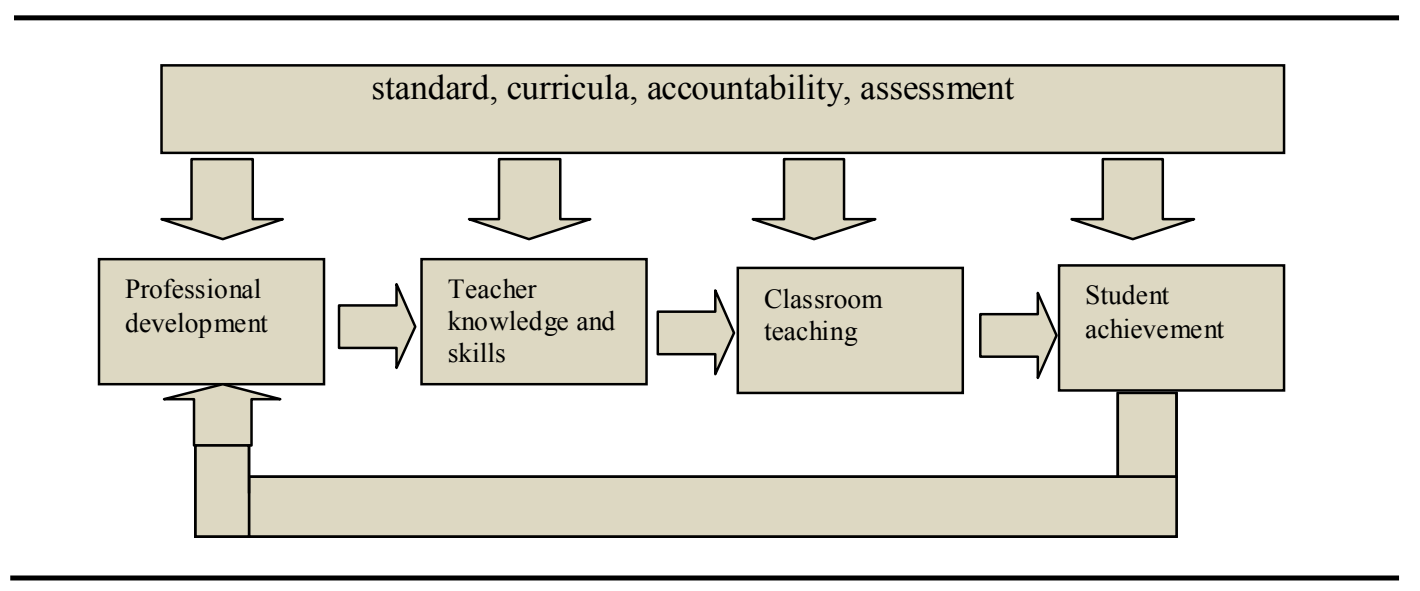

How professional development affects student achievement (Yoon, Duncan, Lee \& Shapley, 2007, p. 4)

Facing those various challenges, as educators, teachers should not be able to manage their classroom (students) but also their own self. Teachers should be able to manage their teaching force (Esteve, 2000) since performing multiple diverse roles can lead to occupational stress (Grasha, 1987; Grasha, 1989, cited in Grasha, 2002). This means that in their professional development process, teachers should learn how to manage their own (personal) learning process and their students' learning operation. Thus, teachers should build inward and outward capacity. Their professional development should affect themselves and their teaching practice (Desimone, Porter, garet, Yoon \& Birman, 2002). Inward competency means they have to be able to be self aware of their learning process. Competent teachers tend to develop self consciousness when their teaching practice needs improvement insted of criticizing their students for teachers' defective pedagogy (Darling-Hammond, 2000).

The other capacity, the outward competency means that they should be able to apply what they learnt to facilitate or enhance their students learning. This self awareness will lead teachers to explore chances around them to enhance their learning. The most effective professional development activity is action which focuses on motivating teachers to explore chances around their environment which can support them to learn and grow (Birman, Desimon, Porter \& Garet, 2000). The outward impact of professional development orients to improving students learning (Birman, et., al., 2000; Supovitz \& Turner, 2000; Borko, ). What teachers need in 
their professional development is skill or knowledge which straightly can improve their teaching (Fullan \& Miles, 1992, cited in Guskey, 2002). The inward and outward impacts indicate that there is there is close relationship between the personal and professioanl context of teachers development. Personally, as selves, teachers can enhance their knowledge and professionally, as teachers, they can teach better.

The most vital or the heart of teachers' professional development is teachers' changes. It is not only the changes in their cognition (the increasing knowledge), but the more important is changes in their beliefs or values (metacognition). There are three main objectives of teachers' professional development programs: increasing teachers' competence in teaching and managing classroom, shifting their values and beliefs, and raising students' achievement (Guskey, 2002, p. 383). Furthermore, Guskey (2002) argues that to change teachers' beliefs and values, professional development action should focus on growing teachers' feeling that it is urgent for them to increase their teaching quality and allowing them to see result of their effort instead of giving the first priority on changing teachers' beliefs and values. This is as Guskey (2002, p. 383) described in the following figure.

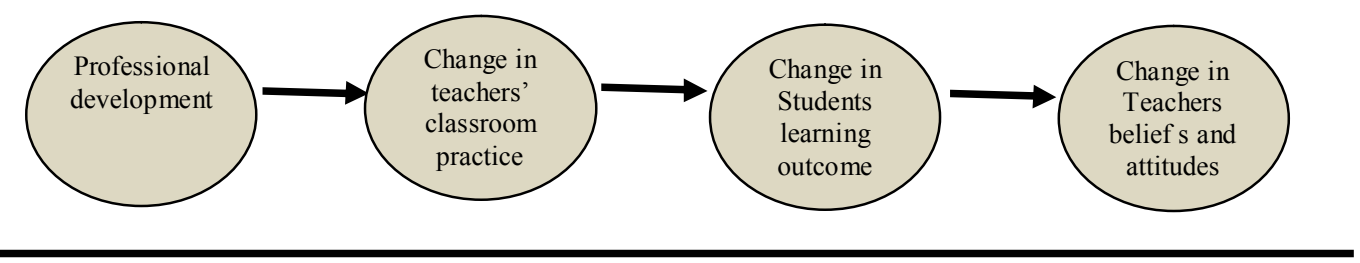

A model of teacher change (Guskey, 2002, p. 383)

The other foundation of teachers' development is the aspect of autonomous or self-regulated learning. This implies that to learn and develop, teachers need inner drive. Self-regulated learners possess self-awareness, motivation and meta-cognition on what they need or should attain (Boekaerts, 1996). There are several elements which support the construct of self-regulated learning: self-efficacy, willingness to practice, commitment, time management, meta-cognitive awareness, and efficient strategy (Boekaerts, 1996). In their self-regulated learning, it is not sufficient for 
teachers to only perform routine work, but they should challenge their own selves to increase their competency and acquire higher knowledge. Teachers should not always do the same thing ("on the-road-to-automaticity") but they should try different learning and (Boekaerts, 1996). To grow, teachers should be adaptive learners (Hammerness, Darling-Hammond, Bransford, Berliner, Cochran-Smith, McDonald \& Zeichner, 2005). Teachers should be able to adjust themselves to complexity, changes, and become more flexible (Darling-Hammond, 2006). They do not avoid changes, but they work to increase their knowledge and skill to meet the new demands as the result of changes. However, Darling-Hammond (2005) recommends teachers to not only become adaptive learners but also maintain their routine expertise. This is as argued by Darling-Hammond (2006), who also quotes the concept of Hatano and Inagaki (1986), Bransford, Brown \& Cocking (1999), as follows:

\footnotetext{
...teachers must become "adaptive experts" (Hatano \& Inagaki, 1986; Bransford, Brown \& Cocking, 1999) who cannot only use routines that afford greater efficiency, but also their ability to innovate where routines are not enough-to figure out what the problems are when the students are not learning and to adapt materials, teaching strategies or supports accordingly. Adaptive learners also know how to continuously expand their expertise, restructuring their knowledge and competencies to meet new challenges. Preparing teachers who can learn from teaching, as well as learning from teaching, is a key challenge for teacher education today, one that these seven programs successfully engage." (p. 11).
}

The above extract highlights teachers development from teaching and learning process. It emphasizes the roles of teachers experience. Human experience and reflexive consciousness is the meaning of their life (Dilthey, 1985, cited in Van Manen, 1990). These experiences occur during the entire course of teachers life. Since the stimulant of professional development, experiences, exist during the life, teachers should perform professional development from learning experience during their life. This indicates that teachers professional development should be viewed as process instead of just the end product. The vital determinant for successful teachers professional development is the process of maintaining change as stimulant for learning and viewing developing as a process instead of just collection of activity (Guskey, 2002). Thus, how teachers perceive and treat experience are essential for laying the foundation of teachers development. 
Professional behavior is closely related to internal motivation and longlife learning. It is difficult for teachers to be able to sustain their high level of professionalism without having self awareness. Longlife professionality also entails that teachers are not performing restricted professionality, but extended professionality by wecoming and adapting educational changing (Hoyle, 1980, p. 49, cited in Day, 1999, p. 5). Longlife and sustainable professionalism needs higher level of loyalty. When teachers do not possess real professionalism, they will not be able to endure their professionalism because they continuously should be injected by external motivation. This is relevant to the quotation of to be professional teachers below:

\footnotetext{
“...displaying ....degrees of dedication and commitment, working long hours as a matter of course and accepting the open-ended nature of the task involved, which often impinged upon home and personal life...it also entailed maximum effort to 'do the best you possibly can' and a constant quest for improved performance. At the same time it involved developing appropriate and caring relationships with students, as well as dealing 'professionally' with colleagues, parents and other external agencies where appropriate. Finally, because of the complexities of the task of teaching and the obligation to meet varying individual needs, high level of skill were necessary to respond intelligently to multiple demands in a complex and changing environment...."(Helsby, Knight, McCulloch, Saunders \& Warburton, 1997, pp. 9-10, cited in Day, 1999, p. 5).
}

The above quotation implies that to be professional teachers should continuously do their routine task very well, but also improve their quality of knowldge. They also should be adaptive to their surrounding.

\section{Factors Contributing to Teachers' Professional Development}

It is apparent that teachers play key role in their own attainment of professional development process. It depends on teachers' motivation, perception on experience and changing, background and beliefs and values. However, the increasing quality of teachers is not entirely dependent on teacher self factors. This is because all teachers have their own individual and social dimensions. In their social life, teachers are becoming members of various groups and developing social attachment with others (Wei, Russell \& Zakalil, 2005; Swann, Polzer, Seyle \& Ko, 2004; Triandis, 1989). This indicates that surroundings or environment can affect 
teachers' efforts and outcomes of professional development. There are several external factors which also contribute to teachers' professional development. This is as represented by the following figure.

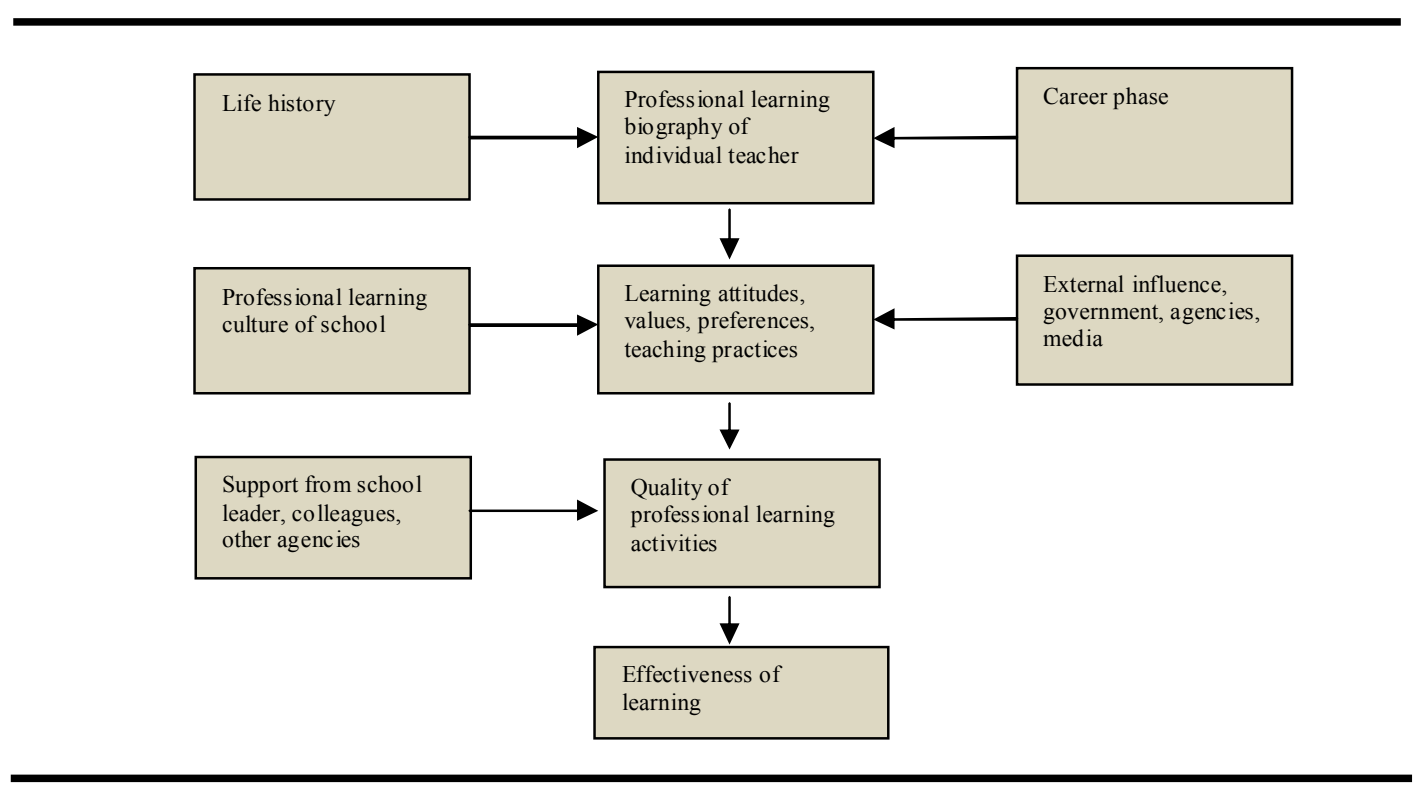

Factors contributing to the quality of professional learning (Day, 1999, p. 4)

The above figure implies that there are two primary aspects affecting teachers' process to develop themselves. Those are teachers' factors (components within teachers' self), which are represented by several factors: life history, professional learning biography of individual teacher and career phase and the other factor is external or surrounding factors including professional learning culture of school, government, agencies, media and support from school leader, colleagues, and other agencies.

This is relevant to affecting factors proposed by Korthagen (2004). Korthagen (2004) argues that the success of teachers' professional development are dependent on several facets: mission, identity, beliefs, competencies, behavior and environment. In his onion model (Korthagen, 2004, p. 80) puts the elements of mission, identity, beliefs, competencies, behavior separated from the facet of environment. This implies that Korthagen (2004) identifies that there are teachers' self factor and environment factors operating in teachers' development. 
There are two forces working in teachers' development. Those are teachers' self and environment. From those two facets, Joyce (1975, p. 130, cited in Korthagen, 2004, p. 79) highlights teachers' individual maturation which is stimulated by need of self-actualization as the most important factor. Similarly, Bullough (1997, cited in Korthagen, 2004, p. 83) stresses the strong role of teachers' internal states by mentioning that teachers' positive perspective of their professional identity and personal identity element are essential components. It is possible that there is incongruent situation. When this happens teachers inner state to learn can be affected and vice versa. Teachers can grow maximally when there is congruence between their inner and outer facets (Shaw, 1975, cited in Korthagen, 2004, p. 87). This also indicates that learning is not only individual process, but also social functioning (Cobb, 1994, cited in Desimone, 2009, p. 182). Teachers' professional development always involves the context (environment) (Borko, 2004). Day (1999) argues that culture which develops in working place, leadership and colleagues can significantly influence teachers' learning process. Thus, teachers' personal and environment dimension are closely related.

\section{Teachers' Learning Engagement and Practice}

Self-directed and autonomous teachers know how to develop without waiting for formal instructions and chances. The essence of teachers development is teachers' capacity to engage in personal pursuit to progress (Korthagen, 2003). They explore their environment and daily activities to improve themselves. They learn from experience (Johnson \& Golomber, 2002; Clement \& Vandenberghe, 2000). There are three main ways of learning for teachers: learning from classroom practice, participating in school communities and attending courses or workshops (Desimone, 2009). Similarly, Day (1999, p. 3) identifies four main learning access which can support techers: "direct teaching (for example: conferences, courses, workshops, consultations), learning in school (for example: peer coaching, critical friends, quality review, appraisal, action resaerch, portofolio assessment, working on tasks together), learning out of school (for example: reform networking, schooluniversity partnership, professional development centres, subject networks and 
informal groups), and learning in classroom (through for example: students' response).

This implies that teachers should be able to learn alone (independently) and together (collaboratively) (Johnson \& Johnson, 1975). This means that independently, teachers should be able to find ways for improving themselves and dependently, they can support their individual learning with cooperative and collaborative learning.

\section{Learning from Teaching Practice}

It is apparent that school and classroom are the areas of teachers. These areas are their everlasting materials for learning. What teacher should learn is available there. What teachers should do is exploring their learning areas. This means that teachers can learn from their practice. There is a shift in teachers' learning area from traditional approach to realistic way, in which teachers learn from their teaching practice intead of from their theory only (Korthagen \& Kessels, 1999). Many teachers education program fail, cannot fill the hole between theory and practice because there is insufficient congruence between theory and teachers' situation/environment (Corporal, 1988, cited in Korthagen \& Kessels, 1999), teachers do not reinforce knowledge that they already gained, they do not practice it (Katz, Raths, Mohanty, Kurachi \& Irving, 1981, p. 21), and there is frequent conflicting circumtances between real situation (actual problem) and theory (Clark \& Lampert, cited in Korthagen \& Kessels, 1999). Educational theories which are given during teacher education program usually fade out when teachers go back to their teaching (Zeichner \& Tabachnick, 1981, cited in Korthagen \& Kessels, 1999). The materials, trainings or education which are given in teacher education program should be sustained by internal aspects. Korthagen and Kessel (1999, pp. 8-9) state several factors which can provide internal push: "feeling, former similar experience, values, role perceptions, needs or concerns, and routines." Thus, to be able to sustain their development process, teachers should rely on unaided experiences.

The below figure represents how teachers should be able to be automatic in their learning. 


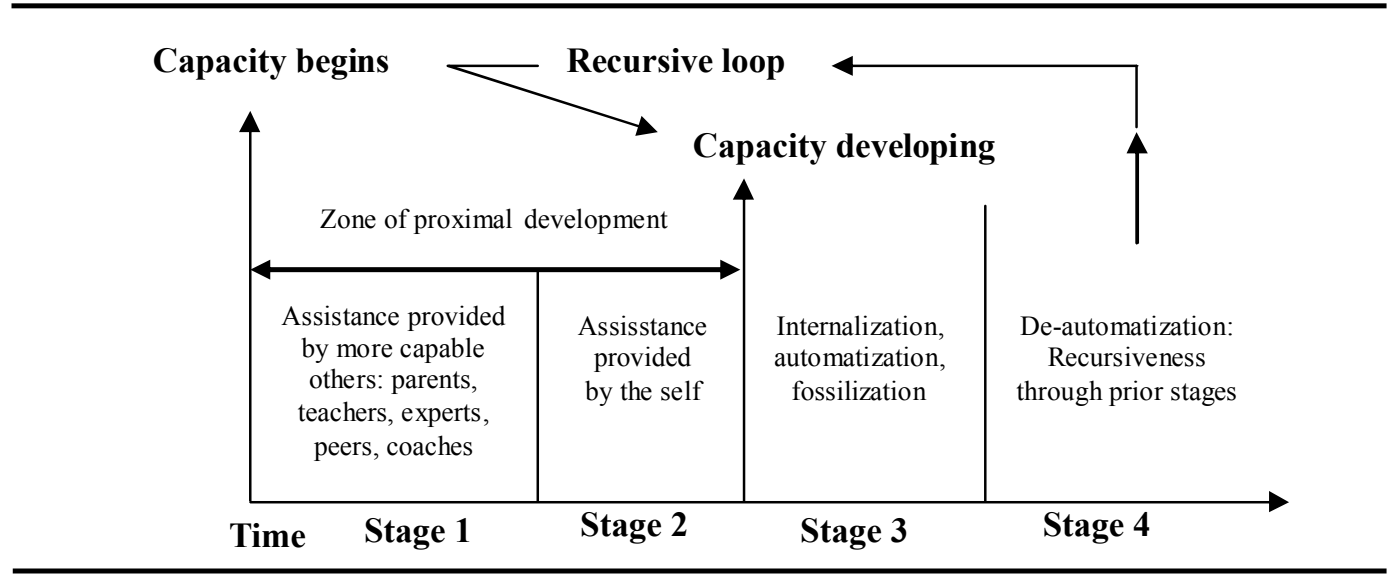

Four stages of assisted performance (Gallimore \& Tharp, 1990, cited in Admiraal \& Wubbels, 2005, p. 317)

Teachers can develop by learning from their teaching practice. Classroom and their activities during teaching or learning to prepare their teaching materials can provide wide and invaluable unaided experience. Through this way, teachers can develop naturally. To be able to grow, teachers should have several knowledges for teaching: knowledge of learners which includes knowledge of learning, human development, and language, knowledge of subject matter and curriculum including the objectives of education, skills development, subject matter, and content,and knowledge of teaching which covers content and content pedagogy, teaching diverse learners, assessment, and classroom management (Darling-Hammond \& Bransford, 2005, p. 11, cited in Darling-Hammond, 2006, p. 5). Teachers should acquire those knowledge and constantly update their knowledge. Teachers should be ready to understand and accept new concepts in their daily life since the changing era demands their students to e adaptive and learn many new areas (Esteve, 2000). Thus, teachers' learning and or development is not a linier process, but it is a cyclic process. As mentioned by Korthagen (1985, cited in Admiraal and Wubbels, 2005) teachers' learning process should in the circle of action-looking back on the actionawareness of essential aspects-creating alternative methods of action-trial. This indicates that teachers' knowledge and learning is not an end-product, but it should be vulnerable and susceptible to development and progress. 


\section{Learning in Professional Communities}

The other source of teachers' development is learning from and with their community. This method of learning is not better to the previous one, but they should work together. Teachers should work alone and together. Teachers should be given time to work based on their autnonomy and collegiality in their community (Clement \& Vandenberghe, 2000). They can engage in collaborative and cooperative learning with their colleagues, in which teachers teach other teachers and some teachers become role models or mentors for other teachers. This method can provide signpost for teachers to look at back to their teaching.

It is possible that when teachers work alone they cannot see other teachers work or teaching. They can be trapped in their daily and routine activities. Going out, working with friends and sharing ideas can provide access for teachers to encounter new things and update their knowledge. Knowldege spreads across teachers' daily teaching life (practice), but to understand it, teachers should reflect and share with others (Vescio, Ross \& Adams, 2007). Today's teachers need to participate in learning community because they should fulfill multiple roles and changing curriculum ( Teachers' learning communities can be base for teachers' change (Wood, 2007). Moreover, teachers' learning community is not only bring advantage for teachers' self/individual development, but also school or community progress (Alberta Education, 2006) and school capacity to create new things (Giles \& Hargreaves, 2006; Bielaczyc \& Collins, n.d.; Hord, 1997). This implies that school elements (factors) are also contributing to teachers' success of learning.

Teachers' professional communities indicate that to develop, teachers should also learn instead of only teaching. There are several aspects that school and teachers should think and consider when they implement or participate in these communities: (1) assuring the improvement/progress of students, which encourages all teachers and school staff to assess and reflect their teaching, (2) growing collaborative culture which focuses on developing collegial climate, (3) concentrating on students' achievement (DuFour, 2004). This collaborative culture includes sharing, reflecting and being ready to face danger as the consequences of change (ada di artikel impact of professional community, hal. 84). 
Professional community highligts the importance of social learning. Learners cannot learn alone all the times. They need to share knowledge with others. The idea of learning community grounds on Dewey's concept that all human are social nature (Killlpatrick, Barrett \& Jones, 2003). Teachers should learn together in social setting (Pea, 1993, p. 48, cited in Kilpatrict, Barrett \& Jones, 2003) and supportive climate in which they communicate, jointly create or discuss issues, validify their ideas (artikel professional learning community, hal. 3). Moreover, Newmann and Wehlage (1995, cited in Morrissey, 2000) believe that learning community can help teachers to respond to different students' demands. By involving in this activities, teachers can prepare themselves or anticipating for changing, forecast the upcoming needs of their students, and reflect methods that they already have implemented (Morrissey, 2000). Teachers who are actively participate in this learning community also develop high level of self confidence to fulfill their students' necessity (Hord, 1997). Moreover, teachers who get support in their learning communities tend to develop firmer commitment than teachers who do not share in their community (Hord, 1997).

To support their teachers to engage in teachers' professional communities, schools should develop certain characteristics: (1) supportive and shared leadership, (2) shared values and vision, (3) learning together and implementing their learning, (4) supportive conditions, and (5) shared personal practice (Morrissey, 2000). Furthermore, Morrissey (2000) states that there are several contextual factors which contribute to schools' success in learning communities: schools, community, district and state-aspects (Morrissey, 2000). Similarly, Newmann, et., al. (1996, cited in Vescio, Ross \& adams, 2007) list several components of successful professional learning communities: collective values and norms in group, persistent goals/objectives to improve students' learning, contemplative sharing among group members, being motivated to practice, and concentrating on working together. 


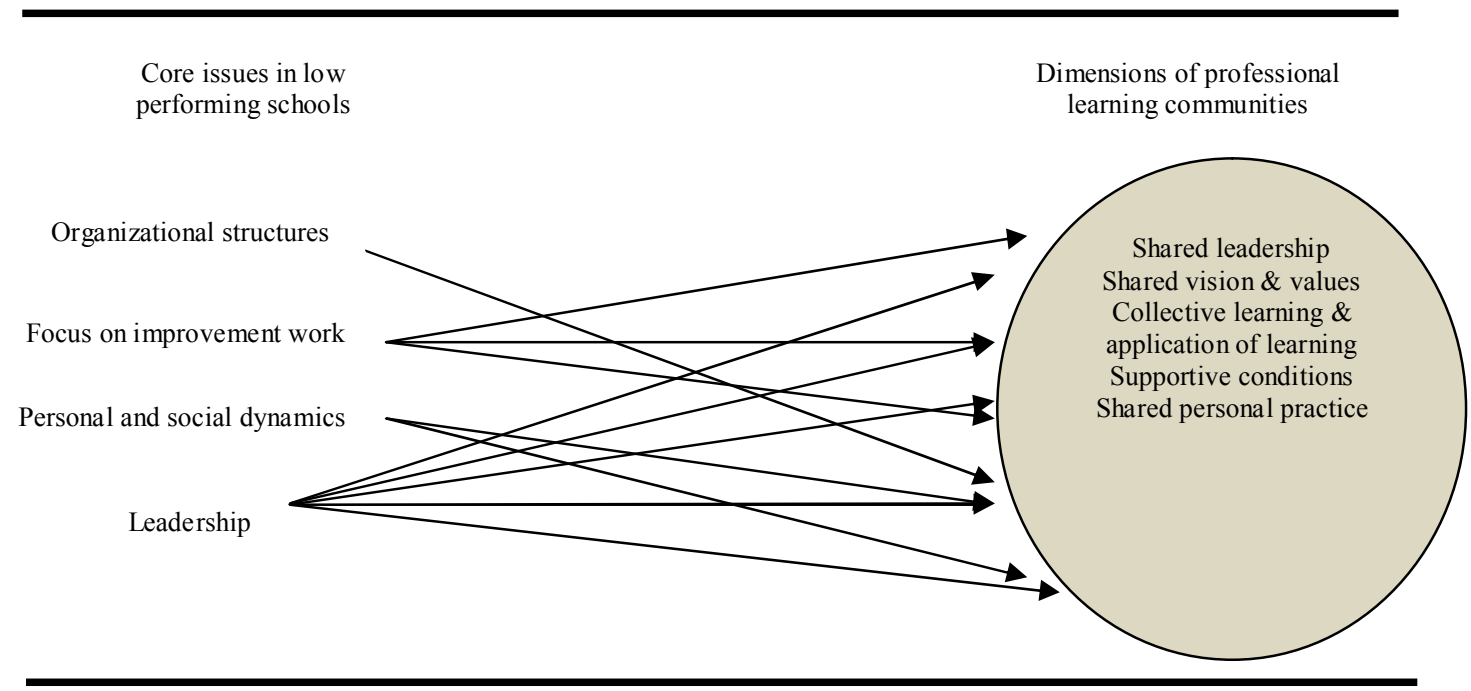

Relationship of core issues and professional learning dimensions (Morrissey, 2000, p. 13)

Professional learning community occurs in a context. That is school context. This means that teachers' learning in their professional community will improve their schools and vice versa. This teachers and school improvement is expected to be able to improve students' quality. Teachers learning is closely related to school development (Morrissey, 2000). Thus, schools' performance can be improved by activating their teachers' professional community. Tools to activate teachers' learning community are related to schools and teachers' individual dimensions. This is as shown in the above figure.

From all of the above elements, teachers' willingness or motivation to learn consistently is the primary ingredient for successfull teachers' learning community (Vescio, Ross \& Adams, 2007). This important emphasis on teachers' aspect entails that as the individuals/persons, teachers have significant roles in activating or creating collaborative culture in their school. As argued by Hord (1997), it is individuals who change organization. The other teachers' aspect is relating to teachers' capacity to maintain their motivation to engage in learning community. Frequently, teachers are very motivated in their first meeting or initial phase. They are very active to come, but when their work is getting overloading, they tend to be absent from their community or even do not come again. To achieve the desired result, teachers should be persistent. This means that activities in learning community should be regular and continuous. Learning community exists "where 
people continually expand their capacity to create the results they truly desire, where new and expansive patterns of thinking are nurtured, where collective aspirations is set free, and where people are continually learning how to learn together' (Senge, 1990, p. 3, cited in Hord, 1997, p. 10). Different from Hord (1997) who emphasizes on teachers' self, Stoll, Bolam, McMahon, Wallace \& Thomas (2006) highlight the signficant link between teachers' self and collective competence. This competence includes spirit, skill, constructive learning, organizational condition, culture and facility (Stoll, Bolam, McMahon, Wallace \& Thomas, 2006).

Since learning community entails a meaning that teachers should work in group, the essence of learning community is collaboration in group. Learning community has shared objective to grow together. This shared objective can be obtained by grow group bond and develop new ideas (Kilpatrick, Barrett \& Jones, 2003). Schrage (1990, cited in Kilpatrick, Barrett and Jones, 2003) identifies three main components in collaborative working: readiness to get involved, having specialization and develop effective communication. Within the construct of learning community, members have weaknesses in accomplishing their tasks and these shortcomings can be overcame by working together (Schrage, 1990, p. 6, cited in Kilpatrict, Barrett \& Jones, 2003). This entails that professional learning community dicusses issues that they encounter during their routine/daily tasks. As mentioned by Vescio et., al. (2008), new ideas can be generated from day to day experience, it can be developed through the process of reflection and sharing.

\section{Learning through Researching}

The concept of field or schools as the source of teachers' knowledge implies that teachers can learn from their schools. However, to be able to learn, they should reflect, observe the emerging issues and find the solutions. One of several ways to increase their knowledge is through researching their classroom. The primary effect of research is changing teachers' behaviour (Hopkins, 2008). By conducting research on their classroom, teachers can improve their teaching quality and students' achievement by adressing the field issues which emerge during their process of teaching and learning. This means that they engage in classroom research 
or action research. This type of research intends to respond to practical problems, which are based on reflection and experience to change situation and to achieve improvement (Ebbutt, 1985, cited in Hopkins, 2011). Teachers' capacity to reflect their context or situation in their environment and research it by adopting their lived experience requires awareness. They need sensitivity (Merleau-Ponty, 1968, cited in Van Manen, 1990, p. 36).

Conducting continuous action research is part of teachers' professional development. This demands teachers' self-directed action since it is based on teachers' own need and motivation instead of top-down instruction. As contended by Stenhouse (1984, p. 69, cited in Hopkins, 2011, p. 37), as follows:

\begin{abstract}
"Good teachers are necessarily autnonomous in professional judgement. They do not need to be told what to do. They are not professionally the dependents of researchers or superintendents, of innovators or supervisors. This does not mean that they do not welcome access to ideas created by other people at other places or in other times. Nor do they reject advice, consultancy or support But they do no know that ideas and people are not of much real use until they are digested to the point where they are subject to the teacher's own judgement in short, it is the task of all educationalists outside the classroom to serve the teachers; for only teachers are in the position to create good teaching.
\end{abstract}

This entails that teachers' researching activity requires teachers to be aware of their own need, their own classroom issues, reflection, judgement, and consistency. Performing action research demands teachers to do cycles of several stages instead of doing it in just one cycle. Several theorists suggest cycles of stages of doing action research: plan-reflect-observe-act-revised plan-reflect-observe-act (Kemmis \& McTaggart, 1988, p. 4, cited in Hopkins, 2011, p. 51), cycle 1: identifying initial idea, reconnaissance (fact finding and analysis), general plan, implement action steps, monitor implementation and effects, reconnaissance (explain any failure to implement, and effects), revise general idea, implement next action steps, cycle 2: monitor implementation and effects, reconnaissance (explain any failure to implement, and effects), revise general idea, amended plan, implement next action steps, cycle 3: monitor implementation and effects, reconnaissance (explain any failure to implement, and effects) (Elliot, 1991, cited in Hopkins, 2011, p. 52), action cycle 1: define problem, needs assessment, hypotheses ideas, develop action plan, implement plan, evaluate action, decisions (reflect, 
explain, understand action) and cycle 2: redefine problem, needs assessment, new hypotheses, revise action plan, implement revised plan, evaluate action, and decisions (reflect, explain, understand action) (McKernan, 1996, p. 29, cited in Hopkins, 2011, p. 53). There are several criteria to conduct classroom research: (1) researching should not obstruct (impede) teachers' teaching tasks and their commitment, (2) teachers' research methodology should not require extensive time, (3) the research should be applicable to their classroom, (4) the topic should not be too frustrated and demand teachers to exert their full or total energy, (5) teachers should be concern on the ethical aspects, (6) teachers should adapt to new policies and ideas in their schools (Hopkins, 2011, pp. 59-60).

Learning through researching helps teachers not only understand the practical problems, but extending their knowledge or ways of thinking into knowing the theoretical foundation underpinning the problems. To improve their knowledge in research domain, teachers should develop strong theoretical basis and practice, comprehend the circumstances in their conceptual foundation, and structure knowledge to allow them to recall their knowledge and put them into action (Darling-Hammond \& Bransford, 2005, p. 366). Thus, teachers should not only emphasized their research on practical basis only, but also understand theories behind the practice.

\section{Reflection in Teachers' Learning}

All methods of teachers learning include reflection as an essential component in teachers' learning. Teachers need to reflect their teaching and learning experiences. One of several principles in teachers' development is teachers' development should be linked to teachers' former experience (Nurkamto, 2014). In their reflective process, teachers should be able to extract key features of meaningful learning from their experiences (Darling-Hammond \& Bransford, 2005, p. 85). Reflection in action means teachers are becoming conscious of what they are thinking, feeling, and doing when they are involved in certain activities (Nurkamto, 2014). There are several levels of reflection: descriptive reflection which tends to tell what happens in the classroom, evaluative reflection includes teachers' 
judgement on what happened in their classroom, critical reflection includes analyses on what is effective and ineffective and imaginative reflection which means that teachers look at classroom scenarios and make suggestions about how lessons could be taught differently and improved (Hickson, 2011, cited in Coleman, 2014).

Teachers can reflect their experiences through several ways. Brookfield (1995) suggests several lenses for teachers to view their teaching and learning: teachers' autobiographies, in which they reflect their own experience and see how other people view their teaching and learning, through students' perspectives, in which teachers view their teaching and learning from students' position, through other teachers' experiences, in which teachers invite their colleagues to observe and share ideas about their teaching and learning, and theoretical literature, in which teachers consult their position by analyzing related literature. These various lenses indicate that teachers' sources of knowledge are situated in their daily life or their practical experiences. However, they are still becoming raw material of teachers' knowledge until teachers perform reflection to process their knowledge.

\section{Conclusion}

During their professional career, teachers should grow and develop themselves. They should not only teaching, but also learning. There are three main sources of teachers' learning. Those are learning from their teaching and classroom, learning through sharing in professional communities and learning from their research. Experiences can increase teachers' knowledge and competence. However, experiences are still raw ingredient, teachers still have to reflect their experiences to absorb the knowledge inside. 


\section{Reference List}

Admiraal, W. \& Wubbels, T. (2005). Multiple voices, multiple realities, what truth? Students teachers' learning to reflect in different paradigms. Teachers and teaching: Theory and Practice, 11, 3, 315-329.

Alberta Education (2006). Professional learning communities: An exploration. InPraxis Group Inc., 1-80.

Bielaczyc, K. \& Collins, A. (n.d.). Larning communities in classrooms: A reconceptualization of educational practice. In C., M. Reigeluth (ed.). Instructional design theories and models, vol.II. Mahwah NJ. Lawrence Erlbaum Associates.

Birman, B., F., Desimone, L., Porter, A., C. \& Garet, M., S. (2000). Designing professional development that works. Educational Leadership, 28-33.

Boekaerts, M. (1996). Self-regulated learning at the junction of cognition and motivation. European Psychologist, 1, 2, 100-112.

Borko, H. (2004). Professional development and teacher learning: Mapping the terrain. Educational Researcher, 33, 8, 3-15.

Brookfield, S., D. (1995). Becoming a critically reflective teacher. San Fransisco: Jossey-Bass.

Clement, M. \& Vandenberghe, R. (2000). Teachers' professional development: A solitary or collegial (ad)venture? Teaching and Teacher Education, 16, 81101.

Coleman, H. (2014). Teachers have different needs: How can professional development be made relevant for every teachers? SiliwangiUniversity.

Darling-Hammond, L. (2006). Constructing 21 st-century teacher education. Journal of Teacher Education, 57, 9, 1-15. Retrieved from www.googlescholar.com, on October, 23, 2014.

Darling-Hammond, L. (2006). Powerful teacher education. Lessons from exemplary programs. San Fransisco: John Wiley \& Sons, Inc.

Darling-Hammond, L. (2000). How teacher education matters. Journal of Teacher Education, 51, 3, 166-173.

Day, C. (1999). Developing teachers: The challenges of lifelong learning. Educational change and development series. Bristol: Taylor \& Francis, Inc. 
Desimone, L., M., Porter, A., C., Garet, M., S., Yoon, K., S. \& Birman, B., F. (Effects of professional development on teachers' instruction: Results from a three-year longitudinal study. Educational Evaluation and Policy Analysis, $24,2,81-112$.

Desimone, L., M. (2009). Improving impact studies of teachers' professional development: Towards better conceptualization and measures. Educational Researcher, 38, 3, 181-199.

DuFour, R. (2004). What is a "professional learning community"? Educational Leadership, 6-11.

Esteve, J., M. (2000). The transformation of the teachers' role at the end of the twentieth century: New challenges for the future. Educational Review, 52, 2, 197-207.

Giles, C. \& Hargreaves, A. (2006). The sustainability of innovative schools as learning organizations and professional learning communities during standardized reform. Educational Administration Quarterly, 42, 1, 124-156.

Grasha, A., F. (2002). Teaching with style. A practical guide to enhancing learning by understanding teaching and learning styles. CA: Alliance Publisher, online version, retreived from www.googlescholar.com, on Januray 24, 2014.

Guskey, T., R. (2002). Professional development and teacher change. Teacher and Teaching: Theory and Practice, 8, 3-4, 381-391.

Hammerness, K., Darling_hammond, L., Bransford, J., Berliner, D., Cochran-Smith, M., McDonald, M. \& Zeichner, K. (2005). How teachers learn and develop. In L. Darling-Hammond \& J. Bransford (eds.). Preparing teachers for a changing world.. What teachers should learn and be able to do. San Fransisco: John Wiley \& Sons, Inc.

Hopkins, D. (2011). A teacher's guide to classroom research. ( $4^{\text {th }}$ Ed.). New York: Open University Press.

Hord, S., M. (1997). Professional learning communities: Communities of continuous inquiry and improvement. Southwest Educational Development Lab, Austin.

Ifanti, A., A. \& Fotopoulopou, V., S. (2011). Teachers' perception of professionalism and professional development: A case study in Greece. World Journal of Education, 1, 1, 40-51. Retrieved from www.googlescholar.com, on October, 23, 2014.

Johnson, K., E. \& Golombek, P., R. (2002). Teachers' narrative inquiry as professional development. Cambridge University Press. 
Johnson, D., W. \& Johnson, R., T. (1975). Learning together and alone. Cooperation, competition, and individualization. New Jersey: Prentice-Hall, Inc.

Killpatrick, S., Barrett, M. \& Jones, T. (2003). Defining Learning Communities. Discussion Paper. Centre for Research \& Learning. University of Tasmania.

Korthagen, F., A. (2003). In search of the essence of a good teacher: Towards a more holistic approach in teacher education. Teaching and Teacher Education, 20, 77-79.

Korthagen, F., A. \& Kessels, J., P., A., M. (1999). Linking theory and practice: changing the pedagogy of teacher education. Educational Researcher, 4-17.

Morrissey, M., S. (2000). Professional learning communities: An ongoing exploration. Texas: Southwest Educational Development Laboratory, 1-45.

Nurkamto, J. (2014). Engaging language teachers as a way to pursue sustained professional development. Siliwangi University.

Supovitz, J., A. \& Turner, H., M. (2000). The effects of professional development on science teaching practices and classroom culture. Journal of Research in Science and Teaching, 37, 9, 963-980.

Stoll, L., Bolam, R., McMahon, A., Wallace, M. \& Thomas, S, (2006). Professional learning communities: A review of the literature. Journal of Educational Change, 7, 221-258.

Swann, W., B., Polzer, J., T., Seyle, D., C. \& Ko, S., J. (2004). Finding value in diversity: Verification of personal and social self-views in diverse groups. Academy of Managament Review, 29, 1, 9-27.

Thomas, B., C. (1995). Helping teachers teach well: Transforming professional dveleopment. CPRE Policy Briefs. Reporting on Issues and Research in Education Policy, 1-11.

Triandis, H., C. (1989). The self and social behaviour in differing cultural context. Psychological Review, 96, 3, 506-520.

Van Manen, M. (1990). Turning the nature of the lived experience. In M. Van Manen (ed.). Researching lived experience. Human science for an action sensitive pedagogy. New York: State University of New York Press.

Van Manen, M. (1990). Resarching lived experience. Human Science for an Action Sensitive Pedagogy. New York: State University of New York Press.

Vescio, V., Ross, D. \& Adams, A. (2007). A review of research on the impact of professional learning communities on teaching practice and student learning. Teaching and Teacher Education, 24, 80-91. 